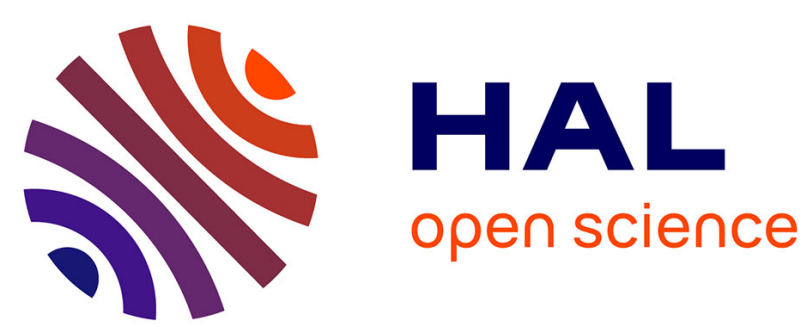

\title{
Effects of connectivity on animal-dispersed forest plant communities in agriculture-dominated landscapes
}

\author{
Cendrine Mony, Juliet Abadie, Assu Gil-Tena, Francoise Burel, Aude Ernoult
}

\section{To cite this version:}

Cendrine Mony, Juliet Abadie, Assu Gil-Tena, Francoise Burel, Aude Ernoult. Effects of connectivity on animal-dispersed forest plant communities in agriculture-dominated landscapes. Journal of Vegetation Science, 2018, 29 (2), pp.167-178. 10.1111/jvs.12606 . hal-01806869

HAL Id: hal-01806869

https://hal-univ-rennes1.archives-ouvertes.fr/hal-01806869

Submitted on 21 Jun 2018

HAL is a multi-disciplinary open access archive for the deposit and dissemination of scientific research documents, whether they are published or not. The documents may come from teaching and research institutions in France or abroad, or from public or private research centers.
L'archive ouverte pluridisciplinaire HAL, est destinée au dépôt et à la diffusion de documents scientifiques de niveau recherche, publiés ou non, émanant des établissements d'enseignement et de recherche français ou étrangers, des laboratoires publics ou privés. 
DR. CENDRINE MONY (Orcid ID : 0000-0002-0061-6521)

Article type : Research article

Co-ordinating Editor : Monika Wulf

Coordinating Editor: Dr. Monika Wulf

Corresponding Author Email Id : cendrine.mony@univ-rennes1.fr

Effects of connectivity on animal-dispersed forest plant communities in agriculturedominated landscapes

\title{
Running head
}

Connectivity effects on animal-dispersed forest plant assemblages

\section{Auteurs}

Mony, C. ${ }^{1}$, Abadie, J. ${ }^{1,2}$, Gil-Tena, A. ${ }^{1,3}$, Burel, F. ${ }^{1}$, Ernoult, A. ${ }^{1}$

1: UMR CNRS ECOBIO, University of Rennes1, Avenue du Général Leclerc, 35042 Rennes Cedex, France

2: RECOVER Research Unit, IRSTEA, 13182 Aix-en-Provence Cedex 5, France

3: InForest Joint Research Unit, CEMFOR, CTFC, 25280 Solsona, Spain

\begin{abstract}

\section{Questions}

How does connectivity affect animal-dispersed plant assemblages in woodlots of agriculturedominated landscapes? Is this effect dependent on zoochorous dispersal modes?

\section{Location}

Long Term Socio-Ecological Research (LTSER) site of "Zone Atelier Armorique" (ca. 150 $\mathrm{km}^{2}$ ), Brittany (Western France)
\end{abstract}




\section{Methods}

We sampled 26 small post-agricultural woodlots embedded in an agricultural matrix (1-7 ha). We assessed the connectivity of each woodlot using habitat reachability metrics (i.e., Proportion of Total Potential Dispersal Flux in the Landscape) calculated along a range of dispersal distances from 100 to $1500 \mathrm{~m}$. This metric was based on graph theory, and was calculated as a function of landscape matrix permeability to animal movement (i.e., seed plant dispersal vectors). We analysed the composition of plant assemblages in the core and margins of woodlots. We calculated the proportion of species richness and cover of zoochorous species within these assemblages and for specific zoochorous modes (i.e., epi-, endo- and dyszoochorous species). We analysed the effects of Proportion of Total Potential Dispersal flux at different dispersal distances and woodlot size on the functional dispersal structure of the plant community using linear models.

\section{Results}

We demonstrated that overall plant zoochorous assemblages only depend on woodlot size in the range of dispersal distances tested. The proportion of richness of zoochorous species within the community increased with habitat size. Connectivity influenced only the relative proportions of the different zoochorous modes, except for the dyszoochorous group, which was primarily influenced by woodlot size. Both epizoochorous and endozoochorous species were impacted by the interaction between connectivity and woodlot area. Connectivity increased the proportion of epizoochorous species richness and the proportion of endozoochorous cover in assemblages in big woodlots. These effects were detected at short dispersal distances. Our results were supported in both total and core plant assemblages.

\section{Conclusion}

This study indicates that both habitat isolation and decrease in habitat size contribute towards shaping the functional structure of the plant community, but they act at different levels of dispersal mode. Our results suggest that in these fragmented landscapes long-distance dispersal has been lost either because of the selection of small-sized animal movements or of the rareness of plant species needing large habitat size. Maintaining woodlot connectivity in the woodland surroundings seems to be sufficient to preserve short-distance dispersal though a more thorough restoration of landscape connectivity is necessary to recover the functional composition of the community with the whole set of dispersal patterns.

\section{Keywords:}

plant assemblages, functional ecology, dispersal traits, plant-animal interactions, zoochory, LTSER “ZA Armorique” (NW France)

\section{Introduction}

Habitat loss is considered as a major driver of plant community dynamics, often resulting in species extinction and decrease in biodiversity (Brooks et al. 2002; Fahrig 2003; Helm et al. 
2006). Because of the reduced patch size, the populations have a higher probability of going extinct in small habitat surfaces (Levins 1970) while big inter-patch distances promote their isolation and, hence reduce the likelihood of recolonization (Young et al. 1996). Forests in Europe have a long history of fragmentation, with extensive forest destruction (Jacquemyn et al. 2003). Nevertheless, in many places of Western Europe, land abandonment and subsequent shrub encroachment and afforestation have been observed since the $20^{\text {th }}$ century (Verburg et al. 2010; Navarro \& Pereira 2012). The greening measures promoted within the European Common Agricultural Policy (Regulation EEC N 2080/92) tend also to increase plantations of forest habitats conducting to numerous but isolated woodlots embedded within the agricultural matrix. Empirical studies have demonstrated that habitat isolation and/or reduced size negatively impact the composition of local forest plant communities by decreasing species richness, especially for the forest specialists (Ehrlen \& Eriksson 2000; Graae \& Sunde 2000; Dupré \& Ehrlen 2002; Jacquemyn et al. 2003; Kolb \& Dieckmann 2005; Honnay et al. 2005). In agriculture dominated landscapes, woodlots offer though the last remnant habitats for the forest species provided they have the capacity to (re)colonize and establish in these isolated ecosystems.

The capacity for long-distance dispersal by plant species at the landscape scale may contribute to their persistence in the landscape, because this strategy compensates for the negative effects of isolation (Cain et al. 2000). Most plant species in forests are dispersallimited, being unable to colonize newly established or far away woodlots (Honnay et al. 2002; Whigham 2004). Such species tend to exhibit low seed production, and often lack specific adaptations for long-distance seed dispersal (Bierzychudek 1982; Dupré \& Ehrlen 2002; Verheyen et al. 2003; Kolb \& Diekmann 2004; Whigham 2004). Consequently, long-distance dispersal events are rare, and are mostly promoted by transport through zoochory (Howe \& Smallwood 1982; Vellend et al. 2003). In fact, animals may serve as important vectors for the 
dispersal of forest plants between isolated patches. However, lack of connectivity (i.e., the degree to which a given landscape facilitates or impedes the movement of organisms among habitat resources; Taylor et al. 1993) may also negatively affect the abundance and diversity of animals, potentially reducing the probability of plant seed dispersal. Grashof-Bokdam (1997) demonstrated that the richness of zoochorous species, especially core forest species, decreases when forest surface around patches decreases. However, this study considered connectivity as a combination of the amount of habitat cover and Euclidian distance to the source patch, which might not completely reflect seed dispersal patterns in zoochorous species. In fact, these patterns are not a simple function of distance from the parent population, but may also be affected by animal behaviour (Nathan \& Muller-Landau 2000; Haddad et al. 2003; Will \& Tackenberg 2008). This type of dispersal behaviour might be impacted by the permeability of landscape elements to animal movement (Bélisle 2005). Thus, more representative functional connectivity indices must be used. In this sense, we would expect the effect of connectivity on zoochorous assemblages to be rather explained by the potential functional connectivity of woodlots, taking into account behavioural responses of organisms to landscape structure and elements (Tischendorf \& Fahrig 2000; Kindlmann \& Burel 2008; La Point et al. 2015).

Vittoz \& Engler (2007) reported four different categories of zoochorous species based on the type of dispersal: (i) epizoochory, when seeds are transported passively by animals in fur; (ii) endozoochory, when seeds are eaten and pass undamaged through the digestive system of the animal; (iii) dyszoochory, when seeds are foraged by animals that store them for winter or accidentally lose them during transport; and (iv) myrmecochory, which is a particular case of dyszoochory, in which ants generally eat seed elaisome but leave the rest of seed untouched. Myrmecochory usually contributes to short distance dispersal, because ants have small home ranges that are limited when the configuration of forest habitat is fragmented 
(Müller-Schneider 1983; De Sanctis et al. 2010). The three other zoochorous categories may contribute to long-distance dispersal (>100 m sensu Cain et al. 2000). However, few studies have empirically measured the actual dispersal distances that are achieved through these different modes. Such actual dispersal distances are calculated using marked seeds or seed trapping (e.g., Tewksbury et al. 2002; Levey et al. 2005). Data are then scarce owing to the difficulty to perform such records. The existing literature measuring actual dispersal has focused on large mammals, including wild herbivores and cattle (Pakeman 2001; Couvreur et al. 2004; Cosyns et al. 2005). These studies suggest these dispersers to contribute to longer distance of propagation through endozoochory compared to epizoochory. However, dispersal distances depend on a variety of attributes, including fur type, seed ingestion, and gut retention rates (Vittoz \& Engler 2007; Will \& Tackenberg 2008). In contrast, fewer studies have investigated small-sized animals as vectors, such as insects, rodents, and birds. In fact, gut retention time in birds may be very short (Fukui 1996; Traveset 1998), suggesting that epizoochory contributes more to long-distance dispersal than endozoochory in small-sized dispersal vectors. Even fewer studies have investigated dyszoochory. An alternative to measuring actual dispersal distances is to assess the potential response of these plant dispersal groups to connectivity loss at different distances of functional connectivity. This may help to detect distance thresholds and infer potential dispersal distances to each dispersal type. This indirect measurement is cost-effective (Calabrese \& Fagan, 2004) and could start determining the scale at which the different modes of dispersal are sensitive.

The present study aimed to analyse how connectivity influences the structure of zoochorous plant assemblages in small post-agricultural woodlots of agriculture-dominated landscapes. Connectivity was assessed through habitat reachability metrics based on graph theory calculated as a function of landscape permeability to animal movement (Saura \& Pascual-Hortal 2007). We only focused on long-distance dispersal (>100 m sensu Cain et al. 
2000), and did not take into account myrmecochory. We specifically tested the following hypotheses:

(i) The abundance and richness of zoochorous species increase with increasing potential functional connectivity of woodlots;

(ii) Connectivity affects the different types of zoochorous mode in a distancedependent manner. Specifically, if dispersal is achieved through large mammals, epizoochorous species may be more dependent on short-distance disruption in connectivity compared to endozoochorous species. Alternatively, if smaller size vectors are involved, endozoochorous species may be more sensitive to connectivity loss at shorter distances compared to epizoochorous species. Because dyszoochory is based on a foraging behaviour, we expect a response similar to endozoochorous species.

\section{Material and Methods}

\section{Study site}

The present study was carried out in the Long-Term Socio-Ecological Research (LTSER) site of "Zone Atelier Armorique" (Bocage -countryside- research site), which is located in Brittany, Western France $\left(48^{\circ} 36^{\prime} \mathrm{N}, 1^{\circ} 32^{\prime} \mathrm{W}\right)$, and covers ca. $150 \mathrm{~km}^{2}$. In order to remove edge effects in the connectivity assessment (Pascual-Hortal \& Saura 2007), we enlarged $3 \mathrm{~km}$ the extent around the LTSER site using the same aerial photography and satellite imagery (see Gil-Tena et al. 2014). The landscape is characterised by an agriculture-dominated area, with a well-developed hedgerow network. This hedgerow network increases in density from north to south, partly driven by soil characteristics and types of agricultural practices. In the south, soil bedrock is granite whereas in the north, soil is on sandstone with more fertile soils than in the 
south. Soil fertility therefore conditions the type of land-use and the parcel size and hence the hedgerow occurrence (i.e., more dense hedgerow network in the south) and may act on connectivity measures (see section "Connectivity assessment of woodlots") which may then covary at coarse scale with these environmental variables.

The study area stands in a context of colonization of post-agricultural woodlots (Fig. 1). Most of the woodlands in the area are composed of originally planted woodlots with further spontaneous colonization by other plants and natural succession. The area comprises a large ancient forest in the south of the site (Fig. 1). Strong modifications of agricultural matrix configuration have been occurring since the 1960s due to the European Common Agricultural Policy and the resulting change in agricultural practices (e.g., increase in parcel size, hedgerows and isolated trees cutting due to reparcelling, abandonment of less productive parcels). These landscape modifications increased the already existing isolation of the woodlots and matrix friction for forest species. In the same time, woodland cover seems to have slightly increased through mostly plantations of post-agricultural woodlots, enhancing the potential habitat area of forest species.

The land-use map was obtained from a photointerpretation of aerial photography (French National Institute of Geographic and Forest Information) in combination with object based and remote sensing aerial classification by RapidEye satellite. Eight land-use categories were identified at $5 \mathrm{~m}$ resolution: crops, semi-natural grasslands, managed grasslands, woodlands, urban areas, water bodies, hedgerows and roads. The hedgerow network and roads were identified from the vector geographic database BDTopo® (2003-2006), which was produced by the French National Institute of Geographic and Forest Information.

Woodlots closer than $25 \mathrm{~m}$ were considered as belonging to the same entity. This aggregation distance threshold was chosen because fairly corresponds to small-distance dispersal of plants (Cain et al. 2000) whereas allowing to have a significant subset of 
candidate woodlands to sample ( $>1 \mathrm{ha}$ ) within the study area according to the spatial resolution of the aerial photography. Following this criteria, we detected 143 entities within the LTSER site according to the land-use map. We then calculated woodlot size and shape (edge:area ratio) and selected 26 woodlots with similar size (close to 2 ha which is the average size of the woodlots in the area) and with high compactness (edge:area ratio below 0.04 which is the median of the woodlots in the area) (Fig. 1; Appendix A). The sampled woodlots were composed of broadleaved trees, dominated by Fagus sylvatica, Quercus robur and Castanea sativa. These woodlots were established on former agricultural lands (arable lands or meadows) mainly during the 20th century and had a similar extensive management.

\section{Connectivity assessment of woodlots}

We computed woodlot connectivity through a graph-theory based reachability metric (Saura \& Pascual-Hortal 2007). For each target woodlot we computed the Proportion of Total Potential Dispersal Flux in the landscape $\left(d F^{*}\right.$; Saura \& Rubio 2010; Gil-Tena et al. 2014), specifically considering in this study as dispersal flux the movement of seed plant dispersal vectors (i.e., animals). We considered as habitat patches the sampled woodlots and the unsampled forests and woodlots larger than 1 ha (Fig. 1). The Proportion of Total Potential Dispersal Flux $\left(d F^{*}\right)$ is based on patch removal experiments and was computed to assess for a certain sampled woodlot (patch $k$ ) the percentage of total potential dispersal flux among all woodlots and forests in the landscape [LTSER site $(+3 \mathrm{~km}$ buffer area)] through the connections of patch $k$ with all other patches in the landscape (i.e., by accounting for the proximity of that woodlot regarding the remaining habitat patches). For a given woodlot (patch) $k, d F^{*}{ }_{k}$ is therefore given by: 
$d F_{k}{ }^{*}=\frac{\sum_{i=1, i \neq k}^{n-1} p_{i k}^{*}}{\sum_{i=1}^{n} \sum_{j=1, i \neq j}^{n} p_{i j}^{*}}$

where $p_{i j} *$ is the maximum product probability of all possible paths between two patches, $i$ and $j$, in the landscape, including direct and non-direct (facilitated by other intermediate patches functioning as stepping stones) dispersal between the two patches (Saura \& PascualHortal 2007). The probability of direct dispersal among woodlots $i$ and $j\left(p_{i j}\right)$ is here modelled as a negative exponential function of the dispersal distance among woodlots $i$ and $j$ (see references therein Saura \& Pascual-Hortal 2007).

In this study we considered inter-patch dispersal distances as a function of landscape permeability and the matrix resistance to the animal movement (i.e., plant seed dispersal vectors) rather than based on euclidian distances. We used a friction map (i.e., impedance/cost for movement cartography) obtained from the land-use categories through classifying them according to their permeability for the movement of forest woodland species (Watts et al. 2010). Friction value distribution corresponded to a mathematical exponential function with minimum friction value of one for forests woodlots larger than 1 ha and a maximum friction threshold of 50 for urban areas (Appendix B); that is to say, for the seed plant dispersal vectors (i.e., animals) moving one meter distance in urban areas is fifty times more difficult than moving $1 \mathrm{~m}$ in woodlands and forests $\geq 1$ ha. The friction values were previously parameterized for the study area by Gil-Tena et al. (2014) and were based on those attributed by Watts et al. (2010) as a function of the vertical structure of the habitat. In Watts et al. (2010), friction values were established based on expert criteria and focusing on generic woodland species in fragmented countryside landscapes in UK. In our study, the distance between each woodlot pair was calculated from the friction map as the accumulated cost (i.e., resistance to movement) along the least cost path by the Graphab 1.0 software (Foltête et al. 
2012; Adriaensen et al. 2003). We selected a minimum planar graph to compute these least cost paths among each patch pair (Appendix A) as Gil-Tena et al. (2014) demonstrated that connectivity indices calculated with minimum planar graph or complete graph are correlated.

We calculated the percentage of dispersal flux for each woodlot $\left(\mathrm{dF}_{\mathrm{k}}{ }^{*}\right)$ using fifteen potential dispersal distances (from $100 \mathrm{~m}$ to $1500 \mathrm{~m}$ at $100 \mathrm{~m}$ intervals) to determine the most relevant distance to characterise functional connectivity depending on zoochorous types. This multiscale approach based on a large range of distances to assess connectivity may enable to detect for fine-grain functional resolution thresholds of community assemblage responses. Each potential dispersal distance was multiplied by the statistical median value of friction in the LTSER site $+3 \mathrm{~km}$ buffer area (Gurrutxaga et al. 2011; Gil-Tena et al. 2014). Each "modified" potential dispersal distance by the median friction value was used to set the decay rate of the negative exponential function at $p_{i j}=0.5$. These calculations were made using Conefor 2.6 (Saura \& Torné 2009).

\section{Floristic surveys}

We sampled each woodlot in the core and margin areas. The core area was defined as the area located close to the centre of the woodlot and at least at $25 \mathrm{~m}$ from the border (Matlack 1993). Because of the large range of possible values for edge effect reported in the literature depending on the set of environmental or organisms considered, we fixed this $25 \mathrm{~m}$-value arbitrarily based on the size range of sites considered. We cannot therefore exclude that assemblages at the centre of the woodlot are affected by edge effects because of the woodlot small sizes. For each woodlot, we selected six $14 \times 5 \mathrm{~m}$ plots using a systematic sampling design: three plots were located in the core area and three plots were located in the margin area. We performed floristic surveys by assessing plant species composition and abundance (in percentage cover) for two vegetation layers: shrubs and herbaceaous plant species. Ferns 
and mosses were not taken into account because their dispersal mode differs from angiosperms and does not rely on zoochory. We did not analyse the composition of the tree layer, due to its dependence on the initial planting and management of the woodlot. From the 140 species pool recorded, 11 species (nine herbaceous and two shrub species) were discarded because they were not considered as forest species (i.e., listed in the French Forest flora, Rameau et al. 1994).

\section{Assessment of dispersal traits in forest fragment communities}

Dispersal traits were assessed using the Baseflor database (Julve 2015). We selected the primary dispersal vector of each species using the following typology: endozoochorous, dyszoochorous, epizoochorous, or other. For a few cases ( $<5$ species, $\sim 4 \%$ of the analysed species pool) where data were not available at the species level, the dispersal mode of close relatives growing in the same habitat was used (e.g., Rumex or Epilobium species). For each woodlot and each type of dispersal vector, we calculated the total number of species and the percentage of cover over the sampling plots (i.e., mean percentage cover over the plots of the woodlots), either considering only plots located at the centre of the woodlot ("core assemblage") or plots located both at the centre and the margin of the woodlot ("total assemblage"). We analysed the effect of connectivity on (i) zoochorous species richness and cover, and their proportions over the core and total plant assemblage (referred to as "zoochorous relative richness" and "zoochorous relative cover", respectively); (ii) the proportion (in species richness and cover) of endo-, dys- and epi-zoochorous species over zoochorous species (referred to as "endo-, dys-, epizoochorous relative richness" and "endo-, dys-, epizoochorous relative cover", respectively). 


\section{Statistical analyses}

Before conducting our analyses, we checked for independence between the ecological variables studied through pair-wise correlations (Pearson correlations). Inside each plant assemblage (total and core), all plant-dispersal assemblage indexes were independent. We also analysed the degree to which these indexes were correlated between core and total assemblages. All indexes were significantly correlated between core and total assemblages but correlations were lower than 0.9 for all variables except for species number and species cover of zoochorous species. Similarity between core and edge assemblages was additionally measured using Sorensen index.

To test for the effect of connectivity on the plant-dispersal assemblage indexes, we used multiple linear regressions with connectivity metrics and woodlot area as explanatory variables. In addition, we checked whether the community response of forest plants to woodland connectivity was mediated by patch size through considering their interaction. When necessary, the index data were log-transformed to improve the normality of the distribution of model residuals. One model was developed for each distance (100 m to 1500 $\mathrm{m}$, at $100 \mathrm{~m}$ intervals), producing 15 models per response variable, with each one being optimised using a backward stepwise selection procedure for explanatory variable selection based on Akaike's information criterion (AIC). We compared these optimized models for each variable using second-order AIC corrected for small sample sizes (AICc). In our analyses, we selected the most supported models as those with $\Delta \mathrm{i}[\mathrm{AICc}]$ within $\leq 2$ units of the model with the lowest AICc (Arnold 2010). We calculated the regression coefficients and the proportion of trait variation that was accounted for by the coefficient of determination $\left(\mathrm{R}^{2}\right)$ in these models. The significance of each explanatory variable in the model was assessed by ANOVAs. All statistical tests were performed using R 2.15.3. software (R Foundation for 
Statistical Computing, Vienna, Austria) through the packages Effect, HH, MASS and AICmodavg.

\section{Results}

Characteristics of the woodlot assemblages

Forest plant assemblages at the woodlot level contained from 10 to 43 species, with between 47 and $187 \%$ percentage cover (Table 1). Sorensen index calculated for assessing similarity between edge and core assemblages varied from 0.31 to 0.84 for total species and from 0.38 to 0.89 for zoochorous species [mean (SD): $0.59(0.10)$ for total; $0.67(0.10)$ for zoochorous assemblages] (Table 1). Zoochorous species represent the majority of species within the assemblages, either in richness (44.19 to $90.91 \%$ of forest species) or cover (48.96 to $99.75 \%$ of forest species), with a large range of variation among woodlots (Table 1). Within zoochorous species, endozoochorous type dispersal was the dominant dispersal mode, followed by epizoochorous and dyszoochorous types.

\section{Effect of connectivity and woodlot area on zoochorous species}

Species richness, cover and relative cover were not dependent on connectivity or woodlot area regardless total or core assemblages (Table 2). The relative richness of species was dependent on woodlot area: the proportion of zoochorous species in the assemblage increased with woodlot size (significant effect for total assemblage, marginal effect for core assemblage, Fig. 2). 


\section{Effect of connectivity on the relative proportion of the dispersal modes of zoochorous species}

We found that woodlot area and/or connectivity did not affect the relative richness of endozoochorous species in total and core assemblages. However, the relative cover of endozoochorous species at the woodlot total assemblage scale was dependent on an interactive effect of both factors (Table 3). The proportion of endozoochorous species in the plant cover decreased with connectivity in small woodlots, but increased in big woodlots (Fig. 3). This effect was only detected for connectivity calculated at a short distance of $100 \mathrm{~m}$, with a relatively high $\mathrm{R}^{2}$ of 0.26 . This effect was not detected in core assemblages.

We detected no effect on the relative cover of epizoochorous species but an interactive effect between connectivity and area on their relative richness both for the woodlot total and core assemblages. The relative richness of epizoochorous species in zoochorous assemblages decreased with connectivity in small woodlots, but increased in big woodlots. This phenomenon was detected for a connectivity distance of 100 to $300 \mathrm{~m}$ for total assemblages and from 100 to $200 \mathrm{~m}$ for core assemblages. The highest $\mathrm{R}^{2}(0.21-0.23)$ was obtained for $200 \mathrm{~m}$ in both types of assemblage.

We observed a significant positive effect of woodlot area on the relative richness of dyszoochorous species, both for woodlot total and core assemblages. In addition, connectivity had a marginally positive effect on species relative richness for total assemblage at the smallest connectivity distance tested $(100 \mathrm{~m})$. Relative cover was independent on both factors, regardless the assemblage being considered. 


\section{Discussion}

Most of the species were dispersed by zoochory (excluding myrmecochorous mode), demonstrating the key role of animals in dispersing forest propagules between local populations. Edge and core assemblages were partially similar indicating a potential smoothing gradient from the border to the centre of the woodlot. Despite this change in species composition, our results showed that connectivity and/or woodlot area had mostly similar effects on the variables measured for both the total and core assemblages suggesting the independence of the pattern from the specific assemblage composition.

\section{Zoochorous plant assemblages depend more on woodlot area than on their isolation}

In contrast to our first hypothesis, plant zoochorous assemblages only depended on woodlot area in the range of connectivity tested. The number of these species in proportion within the community increased with woodlot area, whereas neither richness nor cover (proportional or not) of zoochorous species were dependent on the tested predictors. This suggests that this size effect is not directly linked to a carrying capacity of the woodlot to harbour a large number of plant species, or to act on the local dynamics of plant species, as previously reported by other studies (Honnay et al. 1999). Woodlot size may act on dispersal mode composition by slightly increasing zoochory and/or disfavouring the other dispersal modes. Indeed large woodlots may be less permeable to wind and then disfavour anemochory, which would then indirectly promote zoochorous species proportion in the assemblages. Large woodlots may also favour a large abundance of dispersers, then indirectly affecting plant recruitment (Helliwell 1976; Van Dorp \& Opdam 1987). Large woodlots may harbour a higher number and diversity of animals involved in plant dispersal because they provide a large home range and diversified microhabitats (Honnay et al. 2005), which, in turn, promote 
zoochory. Because the shape of the woodlot (perimeter:area ratio) was standardised in this study, larger woodlots also exhibited larger edge length. When considering animal behaviour, increased edge effects may promote their ability to enter the woodlot and feed on or disperse seeds through their displacement (Murcia 1995).

\section{Connectivity affects the relative proportion of zoochorous dispersal modes}

Connectivity was not related to zoochorous assemblages, but rather acted on the relative proportion of different zoochorous modes (except for the dyszoochorous mode). The dyszoochorous mode was affected by woodlot size, with connectivity having a marginal positive effect. This result might be explained by the confounding effect of species composition. Dyszoochorous species generally correspond to tree plantlets, and are composed of a very small number of species. Their dependence on woodlot size may be the result of higher diversity in microhabitats providing a larger range for species expression. Some dyszoochorous species, surveyed in the herbaceous or shrub layers, such as Fagus sylvatica, Quercus robur and Castanea sativa, are linked to the recruitment of the planted species, which may explain their lack of sensitivity to connectivity.

As expected in our second hypothesis, both epizoochorous and endozoochorous species were affected by connectivity but only in interaction with woodlot area and at relatively short distances (from 100 to $300 \mathrm{~m}$ ). Connectivity at short distances increased the proportion of epizoochorous species richness and the proportion of endozoochorous cover within the assemblage for large woodlot size but the reverse was found for small woodlot size. The influence of connectivity was therefore dependent on a certain carrying capacity of woodlots to harbour animals (i.e., dispersers). Intermediate and big woodlot sizes enable to harbour a large variety of dispersers in contrast to small-size woodlots. In the latter case, 
dispersers may remain less time in small woodlots when connectivity is high and then reduce the possibility to dispersal events of epi- and endozoochorus plant species. The effect on the proportion of species richness in epizoochorous plants vs. cover (i.e., abundance) in endozoochorous plants may be linked with differences in the behaviour of animals involved in endozoochory and epizoochory. We can speculate that when foraging, animals may focus on particular vegetation patches; thus, disseminating greater numbers of endozoochorous seeds of these particular species contributing hence to their large cover. This may be reinforced by the clonal character of these endozoochorous plant species (e.g., Hedera helix, Lonicera periclymenum, Prunus species, Rubus fruticosus). Passive dispersal through epizoochory may involve foraging or non-foraging behaviour (e.g., reproduction, response to predators or territory defence), increasing the likelihood of having a large range of plant species encountering the animal during its movement. These results have however some limitations, as the ability to be dispersed by multiple dispersal vectors is a common phenomenon in most plant species with an average of 2.15 vectors per species (Ozinga et al. 2004). Thus, the ability of a given species to be epizoochorous, endozoochorous or dyszoochorous may also depend on the animals that inhabit or move through the habitat, which may call for complementary analyses based on seed fluxes to better refine how these processes affect plant species richness and abundance. Overall our study demonstrated that endo- and epizoochorous species are favoured only in woodlots with a sufficient carrying capacity for dispersers.

\section{Connectivity affects endo- and epizoochorous dispersal at short distances}

Beyond the effect of connectivity on the respective zoochorous types, plant assemblages were affected by relatively short distances of isolation. Both epizoochorous and endozoochorous modes operated at similar distances of a few hundred meters, which is lower than the 
expected mean distance (i.e., median value of 400, Vittoz \& Engler 1997) reported in the literature for large mammals (Vellend et al. 2003; Mouissie et al. 2005). This may be due to the extinction or rareness of plant species that would depend on long distance zoochory. These extinctions could be the effect of habitat loss selecting out plants that depend on large areas to keep their populations. Our results may alternatively possibly reflect the decrease of consumers that perform long distance movement. Consumers involved in endozoochory may indeed include a large range of animals, from small invertebrates, such as carabid species or snails, to big vertebrates, such as frugivorous birds and mammals. Thus, dispersal distance is highly dependent on the size and mobility of animals (Vittoz \& Engler 1997). Our results suggest that, in such landscapes with small woodlots embedded in a dominant agricultural matrix, feeders may be small animals, because of the limited carrying capacity of such landscapes for hosting viable populations of larger animals (forest specialists). This phenomenon may also apply to epizoochory. These short distances reflect the routine movements of animal species around their habitat patch rather than dispersal movements.

The absence of long-distance dispersal effect on plant zoochorous assemblages in the present study may be also due to the intrinsic characteristics of these long movements which concern only few individuals. The effects of these rare events on plant assemblage structure take a long time to appear and are difficult to detect by diversity indexes. Long-distance movements may also not be well predicted through the connectivity metrics used. First, there can be a discrepancy between the spatial extent of the study area and the actual dispersal distances for the species group under consideration (Fahrig 2013). In this case, relationships may go undetected. We assumed that the spatial extent of the study area was related to the movement range of the studied species but predicting these ranges a priori is difficult, because of the absence of data especially for long-distance dispersal events. Second, there might be also a delay in population response to this type of change in patch isolation, which is 
gradual in time. Populations may indeed not appear to be affected by habitat loss due to behavioural adaptation (With 2015) or to a lagged response to landscape change (Schrott et al. 2005). Landscape dynamic and especially change over time of interpatch connectivity is not often taken into account in connectivity models based on network theory (but see Martensen et al., 2017). These models represent hence dynamic systems by a static network contrary to dynamic network models (Ferrari et al. 2014). They may then underestimate long-distance dispersal event effects because those may depend also on past connectivity (Saura et al. 2014).

Overall, agricultural-landscape matrix, by decreasing the functional connectivity for animal movement, interacts with the biological dispersal distance of plants to constrain their actual dispersal, thus claiming for the development of functional measurements of landscape parameters.

Using a functional approach to assess the effect of habitat isolation on plant assemblages: Implications for forest species conservation in small woodlots

Through this study, we assessed whether habitat isolation affects plant functional structure by selecting species based on their dispersal mode. Yet, this effect was not detected using an index based on specific community structure, underlying the key interest of functional approaches for understanding the processes involved in the recruitment of forest species. More specifically, we demonstrated that both habitat isolation and habitat size are involved in shaping the functional structure of the community, but they act at different dispersal mode resolutions. The reduction in habitat size decreased the proportion of zoochorous species in the community, favouring other dispersal modes. In contrast, habitat isolation through the reduction of connectivity (in interaction with size) affected the type of zoochory (endo- vs. epizoochory) selected. This functional approach could be further refined by taking into 
account traits determining the degree to which plant species have access to particular groups of dispersers out of the dispersers involved in epizoochory, endozoochory and dyszoochory. For instance, certain traits (such as seed size) may be involved in the selection of particular consumers based on their size. In contrast, seed retention time in the guts could determine the type of feeding behaviour of animals. The effect of isolation on dispersal strategy of plant species may also take into account a potential effect of phylogenetic dependency among species. Unmeasured establishment-traits may be additional causes of interspecific variation in colonization capacity and dispersal may be simply correlated to these traits via shared ancestry (Baeten et al. 2015). Unfortunately, many of these traits linked to establishment or dispersal are not available for a large number of species, calling for increased research efforts on this topic. Characterising the plant traits involved in the response to habitat isolation is essential for predicting changes in biodiversity and for proposing conservation actions.

Overall, this study suggests that, in agriculture-dominated landscapes, long-distance zoochoric dispersal mechanisms, have been lost either due to the selection of dispersers of smaller size and lower mobility or to the rareness or extinction of plant species that need larger habitat size to maintain. Maintaining connectivity in the surroundings of woodlots is therefore important for maintaining present day dispersal patterns and plant community characteristics in woodlots but management actions at the larger landscape scale are necessary to restore a more complete set of original community characteristics and their dispersal mechanisms.

\section{Acknowledgements}

We thank B. Clément and Q. Landais for assisting with data collection and J. Nabucet for assisting with land-use maps and connectivity parameterization. We are also grateful to three anonymous reviewers for contributing to improve the final manuscript version with their 
valuable comments. RapidEye imagery was provided by GEOSUD. This work was funded by the French Ministry of Agriculture (DIVA 3 - Agriconnect project: Continuités écologiques dans les paysages agricoles) and supported by landscape database collected in the LTSER sites of Pleine-Fougères (CNRS funding). A. Gil-Tena was funded by the Spanish Ministry of

Economy and Competitiveness (JCI-2012-12089).

\section{References}

Adriaensen, F., Chardon, J.P., De Blust, G., Swinnen, E., Villalba, S., Gulinck, H. \& Matthysen, E. 2003. The application of 'least-cost' modelling as a functional landscape model. Landscape and Urban Planning 64: 233-247.

Arnold, T.W. 2010. Uninformative Parameters and Model Selection Using Akaike's Information Criterion. Journal of Wildlife Management 74: 1175-1178.

Baeten, L., Davies, T.J., Verheyen, K., Van Calster, H. \& Vellend, M. 2015. Disentangling dispersal from phylogeny in the colonization capacity of forest understorey plants. Journal of Ecology 103: 175-183.

Bélisle, M. 2005. Measuring landscape connectivity: the challenge of behavioral landscape ecology. Ecology 86: 1988-1995.

Bierzychudek, P. 1982. Life histories and demography of shade-tolerant temperate forest herbs: a review. New Phytologist 90:757-776.

Brooks, T.M., Mittermeier, R.A., Mittermeier, C.G., da Fonesca, G.A.B., Rulands, A.B., Konstant, W.R., Flick, P., Pilgrim, J., Olfield, S., Magin, G. \& Hilton-Taylor, C. 2002. Habitat loss and extinction in the hotpsots of biodiversity. Conservation Biology 16: 909923.

Cain, M.L., Milligan, B.G. \& Strand, A.E. 2000. Long-distance seed dispersal in plant populations. American Journal of Botany 87: 1217-1227.

Calabrese, J.M., \& Fagan, W.F. 2004. A comparison-shopper's guide to connectivity metrics. Frontiers in Ecology and the Environment 2: 529-536.

Cosyns, E., Claerbout, S., Lamoot, I. \& Hoffmann, M. 2005. Endozoochorous seed dispersal by cattle and horse in a spatially heterogeneous landscape. Plant Ecology 178: 149-162.

Couvreur, M., Vandenberghe, B., Verheyen, K. \& Hermy, M. 2004. An experimental assessment of seed adhesivity on animal furs. Seed Science Research 14: 147-159.

De Sanctis, M. Alfò, M., Attorre, F., Francesconi, F. \& Bruno, F. 2010. Effects of habitat configuration and quality on species richness and distribution in fragmented forest patches near Rome. Journal of Vegetation Science 21: 55-65.

Dupré, C. \& Ehrlén, J. 2002. Habitat configuration, species traits and plant distributions. Journal of Ecology 90: 796-805.

Ehrlen, J. \& Eriksson, O., 2000. Dispersal limitation and patch occupancy in forest herbs. Ecology 81: 1667-1674.

Fahrig, L. 2013. Rethinking patch size and isolation effects: the habitat amount hypothesis. Journal of Biogeography 40: 1649-1663.

Fahrig, L. 2003. Effects of habitat fragmentation on biodiversity. Annual review of Ecology, Evolution and Systematics 34: 487-515.

Ferrari, J., Preisser, E.L. \& Fitzpatrick, M.C. 2014. Modeling the spread of invasive species using dynamic network models. Biological Invasions 16: 949-960. 
Fukui, A. 1996. Retention Time of Seeds in Bird Guts: Costs and Benefits for Fruiting Plants and Frugivorous Birds. Plant Species Biology 11: 141-147.

Gil-Tena, A., Nabucet, J., Mony, C., Abadie, J., Saura, S., Butet, A., Burel, F. \& Ernoult, A. 2014. Woodland bird response to landscape connectivity in an agriculture-dominated landscape: a functional community approach. Community Ecology 15: 256-268.

Graae, B.J. \& Sunde, P.B. 2000. The impact of forest continuity and management on forest floor vegetation evaluated by species traits. Ecography 23: 720-731.

Grashof-Bokdam, C. 1997. Forest species in an agricultural landscape in the Netherlands: Effects of habitat fragmentation. Journal of Vegetation Science 8: 21-28.

Gurrutxaga, M., Rubio L. \& Saura S. 2011. Key connectors in protected forest area networks and the impact of highways: A transnational case study from the Cantabrian Range to the Western Alps (SW Europe). Landscape and Urban Planning 101: 310-320.

Haddad, N. M., Bowne, D.R., Cunningham, A., Danielson, B.J., Levey, D.J., Sargent, S. \& Spira, T. 2003. Corridor use by diverse taxa. Ecology 84: 609-615.

Helliwell, D.R. 1976. The effect of size and isolation on the conservation value of wooded sites in Britain. Journal of Biogeography 3: 407-416.

Helm, A., Hanski, I. \& Pärtel, M. 2006. Slow response of plant species richness to habitat loss and fragmentation. Ecology letters 9: 72-77.

Honnay, O., Hermy, M. \& Coppin, P. 1999. Impact of habitat quality on forest plant species colonization. Forest Ecology and management 115: 157-170.

Honnay, O., Verheyen, K. \& Hermy, M. 2002. Permeability of ancient forest edges for weedy plant species invasion. Forest Ecology and Management 161: 109-122.

Honnay, O., Jacquemyn, H., Bossuytn B. \& Hermy, M. 2005. Forest fragmentation effects on patch occupancy and population viability of herbaceous plant species. New phytologist 166: 723-736.

Howe, H.F. \& Smallwood, J. 1982. Ecology of seed dispersal. Annual Review in Ecology and Systematics 13: 201-228.

Jacquemyn, H., Butaye, J. \& Hermy, M. 2003. Influence of environmental and spatial variables on regional distribution of forest plant species in a fragmented and changing landscape. Ecography 26: 768-776.

Julve, P. 2015. Baseflor. Index botanique, écologique et chorologique de la flore de France. Version: Oct. 30th 2015. http://perso.wanadoo.fr/philippe.julve/catminat.htm.

Kindlmann, P. \& Burel, F. 2008. Connectivity measures: a review. Landscape Ecology 23: 879-890.

Kolb, A. \& Dieckmann, M. 2004. Effects of environment, habitat configuration and forest continuity on the distribution of forest plant species. Journal of Vegetation Science 15: 199-208.

Kolb, A. \& Dieckmann, M. 2005. Effects of Life-History Traits on responses of Plant Speices to Forest Fragmentation. Conservation Biology 19: 929-938.

LaPoint, S., Balkenhol, N., Hale, J., Sadler, J. \& van Der Ree, R. 2015. Ecological connectivity research in urban areas. Functional Ecology 29:868-878.

Levey, D.J., Bolker, B.M., Tewksbury, J.J., Sargent, S. \& Haddad, N.M. 2005. Effects of Landscape Corridors on Seed Dispersal by Birds. Science 309: 146-148.

Levins, R. 1970. Extinctions. In: Some mathematical questions in biology. Lectures on mathematics in the life sciences. 2: 77-107. The American Mathematical Society, Providence, RI.

Martensen, A. C., Saura, S. \& Fortin, M.-J. 2017. Spatio-temporal connectivity: assessing the amount of reachable habitat in dynamic landscapes. Methods in Ecology and Evolution 8: 1253-1264. doi:10.1111/2041-210X.12799. 
Matlack, G.R. 1993. Microenvironment variation within and among forest edge sites in the eastern United States. Biological Conservation 66: 185-194.

Mouissie, A.M., Lengkeek, W. \& Van Diggelen, R. 2005. Estimating adhesive seed-dispersal distances: field experiments and correlated random walks. Functional Ecology 19: 478486.

Müller-Schneider, P. 1983. Verbreitungsbiologie (Diasporologie) der Blütenpflanzen. 3. Aufl. Veröff. Geobot. Inst. ETH Stiftung Rübel Zürich 61: 1-226.

Murcia, C. 1995. Edge effects in fragmented forests: implications for conservation. Trends in Ecology and Evolution 10: 58-62.

Nathan, R. \& Muller-Landau, H.C. 2000. Spatial patterns of seed dispersal, their determinants and consequences for recruitment. Trends in Ecology and Evolution 15: 278-285.

Navarro, L.M. \& Pereira, H.M. 2012. Rewilding abandoned landscapes in Europe. Ecosystems 15: 900-912.

Ozinga, W.A., Bekker, R.M., Schaminée, J.H.J. \& Van Groenendael, J.M.V. 2004. Dispersal potential in plant communities depends on environmental conditions. Journal of Ecology 92: 767-777.

Pakeman, R.J. 2001. Plant migration rates and seed dispersal mechanisms. Journal of Biogeography 28: 795-800.

Rameau, J.C., Mansion, D. \& Duné, G. 1994. Flore forestière française. 1. Plaines et Collines. Ed Institut pour le développement forestier.

Saura, S., Bodin, O. \& Fortin, M.-J. 2014. Stepping stones are crucial for species'long distance dispersal and range expansion through habitat networks. Journal of Applied Ecology 51: 171-182.

Saura, S. \& Pascual-Hortal, L. 2007. A new habitat availability index to integrate connectivity in landscape conservation planning: Comparison with existing indices and application to a case study. Landscape and Urban Planning 83: 91-103.

Saura, S. \& Torné, J. 2009. Conefor Sensinode 2.2: A software package for quantifying the importance of habitat patches for landscape connectivity. Environmental Modelling \& Software 24: 135-139.

Schrott, G.R., With, K.A. \& King, A.W. 2005. On the importance of landscape history for assessing extinction risk. Ecological Applications 15: 493-506.

Taylor, P.D., L. Fahrig, K. Henein \& Merriam, G. 1993. Connectivity is a vital element of landscape structure. Oikos 68: 571-573.

Tewksbury, J.J., Levey, D.J., Haddad, N.M., Sargent, S., Orrock, J.L., Weldon, A., Danielson, B.J., Brinkerhoff, J., Damschen, E.I. \& Townsend, P. 2002. Corridors affect plants, animals, and their interactions in fragmented landscapes. Proceedings of the National Academy of Sciences 99: 12923-12926.

Tischendorf, L. \& Fahrig, L. 2000. On the usage and measurement of landscape connectivity. Oikos 90: 7-19.

Traveset, A. 1998. Effect of seed passage through vertebrate frugivores' guts on germination: a review. Perspectives in Plant Ecology, Evolution and Systematics 1/2: 151-190.

Van Dorp, D. \& Opdam, P.F.M. 1987. Effects of patch size, isolation and regional abundance on forest bird communities. Landscape Ecology 1: 59-73.

Vellend M., Myers J.A., Gardescu S. \& Marks P.L. 2003. Dispersal of Trillium seeds by deer: Implications for long-distance migration of forest herbs. Ecology 84: 1067-1072.

Verburg, P.H., van Berkel, D.B., van Doorn, A.M., van Eupen, M. \& van den Heiligenberg, H.A.R.M., 2010. Trajectories of land use change in Europe: a model-based exploration of rural futures. Landscape Ecology 25: 217-232. 
Verheyen, K., Honnay, O., Motzkin, G., Hermy, M. \& Foster, D. 2003. Response of forest plant species to land-use change: a life-history trait-based approach. Journal of Ecology 91: $563-577$.

Vittoz, P. \& Engler, R. 2007. Seed dispersal distances: A typology based on dispersal modes and plant traits. Botanica Helvetica 117: 109-124.

Watts, K., A.E. Eycott, P. Handley, D. Ray, J.W. Humphrey, Quin, C.P. 2010. Targeting and evaluating biodiversity conservation action within fragmented landscapes: an approach based on generic focal species and least-cost networks. Landscape Ecology 25: 13051318.

Whigham, D. 2004. Ecology of woodland herbs in temperate deciduous forests. Annual Review of Ecology and Systematics 35: 583-621.

Will, H. \& Tackenberg, O. 2008. A mechanistic simulation model of seed dispersal by animals. Journal of Ecology 96: 1011-1022.

With, K.A. 2015. How fast do migratory songbirds have to adapt to keep pace with rapidly changing landscapes? Landscape Ecology 30: 1351-1361.

Young, A., Boyle, T. \& Brown, T. 1996. The population genetic consequences of habitat fragmentation for plants. Trends in Ecology and Evolution 11:413-418.

\section{List of APPENDIX}

Figure A.1: Representation of the woodlands in the study area

Table A.1. Sampled woodlot area and shape and descriptive statistics of interpatch Euclidean distances

\section{APPENDIX B}

Table B1. Decreasing friction values used to model landscape matrix permeability

\section{Figures and tables}


Table 1: Plant community characteristics (Total and Core assemblages). Species richness and cover in percentage (\%, \% may exceed $100 \%$ due to vegetation stratification).

\begin{tabular}{|c|c|c|c|c|}
\hline & \multicolumn{2}{|c|}{ Total assemblage } & \multicolumn{2}{|c|}{ Core assemblage } \\
\hline & Mean (SD) & Min-Max & Mean (SD) & Min-Max \\
\hline \multicolumn{5}{|l|}{ Whole plant community } \\
\hline Richness & $27.5(9.2)$ & $10-43$ & $15.7(5.4)$ & $6-25$ \\
\hline Cover $(\%)$ & $112.0(36.1)$ & $46.8-186.7 .8$ & $101.6(46.0)$ & $31.7-200.3$ \\
\hline \multicolumn{5}{|l|}{ Zoochorous species } \\
\hline Richness & $18.6(5.1)$ & $9-31$ & $11.2(3.2)$ & $6-19$ \\
\hline Cover $(\%)$ & $99.4(32.4)$ & $41.2-167.7$ & $86.4(40.3)$ & $27.3-166$ \\
\hline Relative richness (\%) & $71.1(14.2)$ & $43.6-90.9$ & $74.0(14.7)$ & $40.9-100$ \\
\hline Relative cover $(\%)$ & $91.4(9.2)$ & $65.1-99.8$ & $87.6(19.0)$ & $29.7-100$ \\
\hline \multicolumn{5}{|l|}{ Endozoochorous species } \\
\hline Relative richness (\%) & $47.9(8.4)$ & $30.8-66.7$ & $52.3(11.1)$ & $28.6-72.7$ \\
\hline Relative cover $(\%)$ & $69.4(11.5)$ & $51.0-95.1$ & $67.5(19.3)$ & $14.8-96.5$ \\
\hline \multicolumn{5}{|l|}{ Epizoochorous species } \\
\hline Relative richness (\%) & $29.5(11.0)$ & $11.1-53.9$ & $22.9(13.6)$ & $0-44.4$ \\
\hline Relative cover $(\%)$ & $8.4(7.6)$ & $0.4-26.1$ & $8.6(8.4)$ & $0-34.7$ \\
\hline \multicolumn{5}{|l|}{ Dyszoochorous species } \\
\hline Relative richness (\%) & $18.2(6.3)$ & $9.7-33.3$ & $26.2(12.5)$ & $10.5-50$ \\
\hline Relative cover $(\%)$ & $23.3(15.2)$ & $0.9-50.8$ & $24.4(21.4)$ & $1-87.0$ \\
\hline
\end{tabular}


Table 2: Most supported models according to the AIC framework for woodlot plant assemblages. Models in bold are significant at $p<0.05$; $:$ : $<0.05$; $t: p<0.1$. We did not show columns corresponding to the Connectivity and interaction term (Area $x$ Connectivity), as they are not included in the optimised models.

\begin{tabular}{|c|c|c|c|c|c|c|}
\hline & \multicolumn{3}{|c|}{ General model } & \multirow[t]{2}{*}{ Intercept } & \multicolumn{2}{|c|}{ Area } \\
\hline & Distance & $\mathrm{R}^{2}$ & $\mathrm{p}$ & & $\mathrm{F}$ & \\
\hline \multicolumn{7}{|l|}{ Total assemblage } \\
\hline Zoochorous richness & - & -0.02 & 0.48 & 163.71 & & \\
\hline Zoochorous relative richness & - & 0.14 & $\mathbf{0 . 0 3}$ & 212.66 & $5.10 *$ & 3.23 \\
\hline Zoochorous cover & - & -0.04 & 0.83 & 260.64 & & \\
\hline Zoochorous relative cover & - & 0.06 & 0.13 & -46.85 & & \\
\hline \multicolumn{7}{|l|}{ Core assemblage } \\
\hline Zoochorous richness & - & 0.04 & 0.17 & 138.98 & & \\
\hline Zoochorous relative richness & - & 0.1 & $0.07 \mathrm{t}$ & -23.63 & $3.63 *$ & 2.90 \\
\hline Zoochorous cover & - & -0.04 & 0.78 & 271.94 & & \\
\hline Zoochorous relative cover & - & -0.01 & 0.42 & -44.87 & & \\
\hline
\end{tabular}




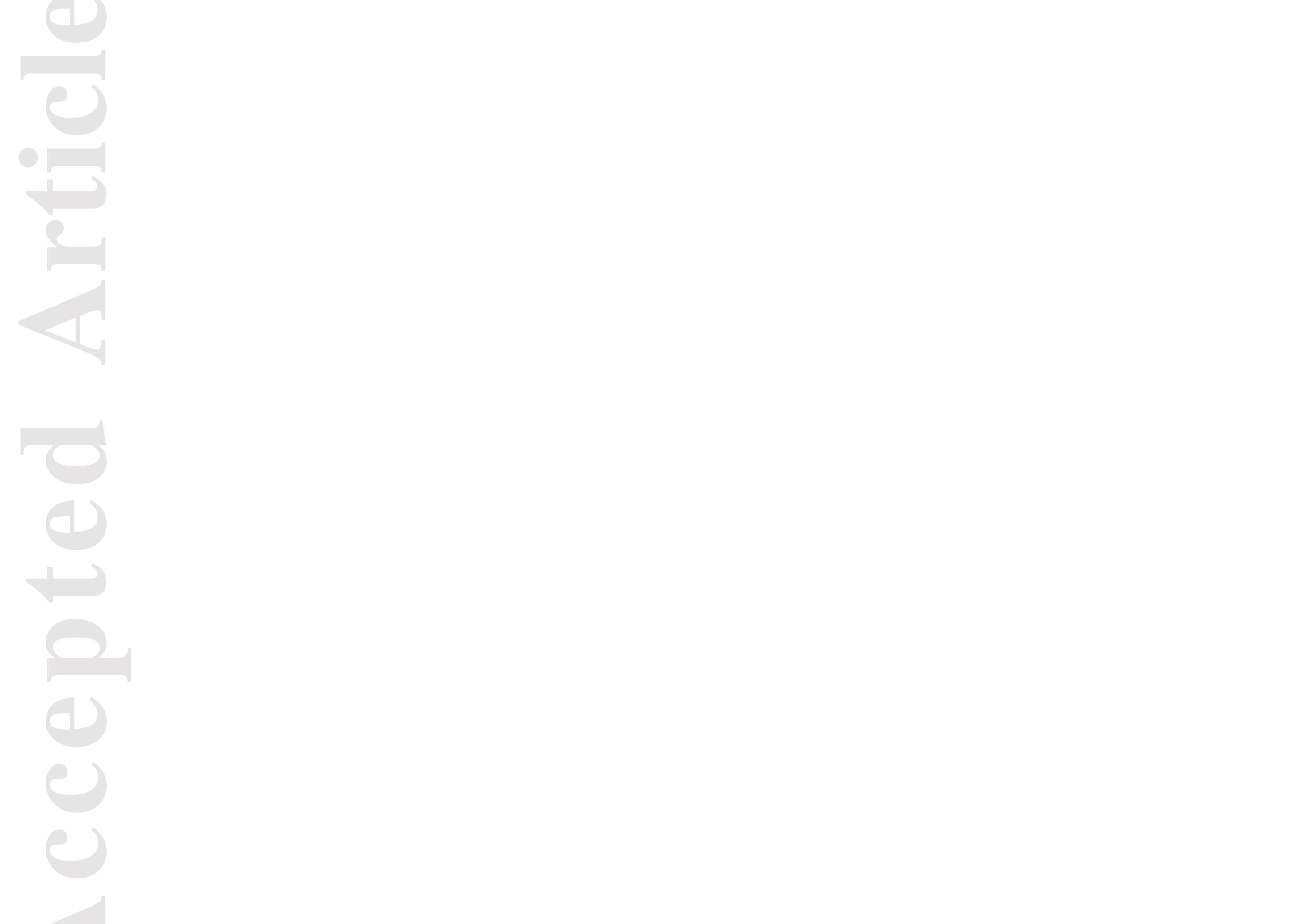


Table 3: Most supported models according to the AIC framework for the different zoochorous types. Richness and cover are expressed as relative to zoochorous assemblage. Models in bold are significant. $* * *: p<0.001, * *: p<0.01 ; *$ : $p<0.05 ;$ t: $p<0.1$.

\begin{tabular}{|c|c|c|c|c|c|c|c|c|c|c|}
\hline & \multicolumn{3}{|c|}{ General Model } & \multirow[t]{2}{*}{ Intercept } & \multicolumn{2}{|c|}{ Area } & \multicolumn{2}{|c|}{ Connectivity } & \multicolumn{2}{|c|}{ Interaction } \\
\hline & Distance & $\mathrm{R}^{2}$ & $\mathrm{p}$ & & $\mathrm{F}$ & Estimate & $\mathrm{F}$ & Estimate & $\mathrm{F}$ & Estimate \\
\hline \multicolumn{11}{|l|}{ Total assemblage } \\
\hline \multicolumn{11}{|l|}{ Endozoochorous } \\
\hline Relative richness & - & 0.13 & 0.11 & & & & & & & \\
\hline Relative cover & $100 \mathrm{~m}$ & 0.26 & 0.02 & 82.08 & 2.53 & -0.04 & 0.18 & -1.10 & $8.96 * *$ & 0.30 \\
\hline \multicolumn{11}{|l|}{ Epizoochorous } \\
\hline \multirow[t]{3}{*}{ Relative richness } & $200 \mathrm{~m}$ & 0.23 & 0.04 & 57.47 & 1.29 & -8.03 & 1.26 & -137.31 & $7.71 *$ & 32.88 \\
\hline & $100 \mathrm{~m}$ & 0.17 & 0.07 & 47.30 & 1.20 & -5.47 & 1.60 & -98.43 & $5.23 *$ & 23.49 \\
\hline & $300 \mathrm{~m}$ & 0.19 & 0.06 & 59.47 & 1.23 & -8.40 & 0.84 & -135.41 & $6.65 *$ & 32.91 \\
\hline Relative cover & - & 0.03 & 0.20 & & & & & & & \\
\hline \multicolumn{11}{|l|}{ Dyszoochorous } \\
\hline \multirow[t]{2}{*}{ Relative richness } & $100 m$ & 0.22 & 0.02 & 13.44 & $5.41 *$ & 0.91 & $3.68 \mathrm{t}$ & 14.60 & & \\
\hline & & 0.13 & 0.04 & 14.23 & $4.86 *$ & 1.40 & & & & \\
\hline Relative cover & - & 0.10 & 0.12 & & & & & & & \\
\hline \multicolumn{11}{|l|}{ Core assemblage } \\
\hline \multicolumn{11}{|l|}{ Endozoochorous } \\
\hline Relative richness & - & -0.002 & 0.34 & & & & & & & \\
\hline Relative cover & - & 0.0045 & 0.30 & & & & & & & \\
\hline \multicolumn{11}{|l|}{ Epizoochorous } \\
\hline \multirow[t]{3}{*}{ Relative richness } & $200 \mathrm{~m}$ & 0.21 & 0.04 & 56.81 & 2.25 & -10.7 & 0.15 & -152.04 & $7.44 *$ & 40.02 \\
\hline & $100 \mathrm{~m}$ & 0.19 & 0.06 & 46.39 & 2.17 & -7.60 & 0.89 & -118.5 & $5.68 *$ & 29.8 \\
\hline & $300 \mathrm{~m}$ & 0.16 & 0.08 & 56.46 & 2.11 & -10.81 & 0.0003 & -136.3 & $5.74 *$ & 38.2 \\
\hline Relative cover & - & -0.002 & 0.34 & & & & & & & \\
\hline \multicolumn{11}{|l|}{ Dyszoochorous } \\
\hline Relative richness & - & 0.21 & 0.01 & 16.56 & $7.82 *$ & 3.4 & & & & \\
\hline Relative cover & - & -0.04 & 0.71 & & & & & & & \\
\hline
\end{tabular}



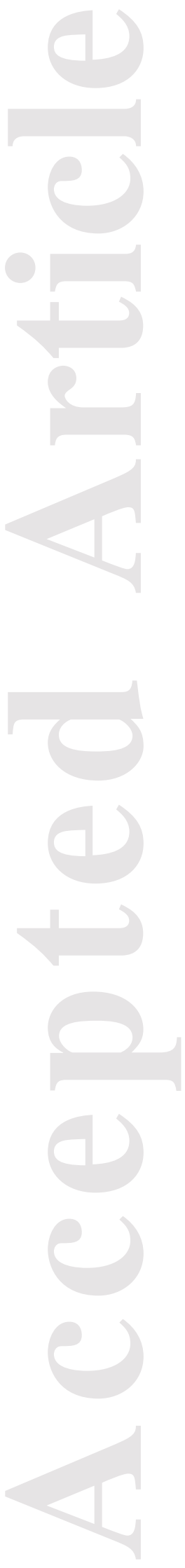
Figure 1: Map of the study site (Armorique Long-Term Socio-Ecological Research LTSER - enlarged with a $3 \mathrm{~km}$ buffer). We show in gray all the woodland habitats with a size over 1 ha and in black those sampled sites

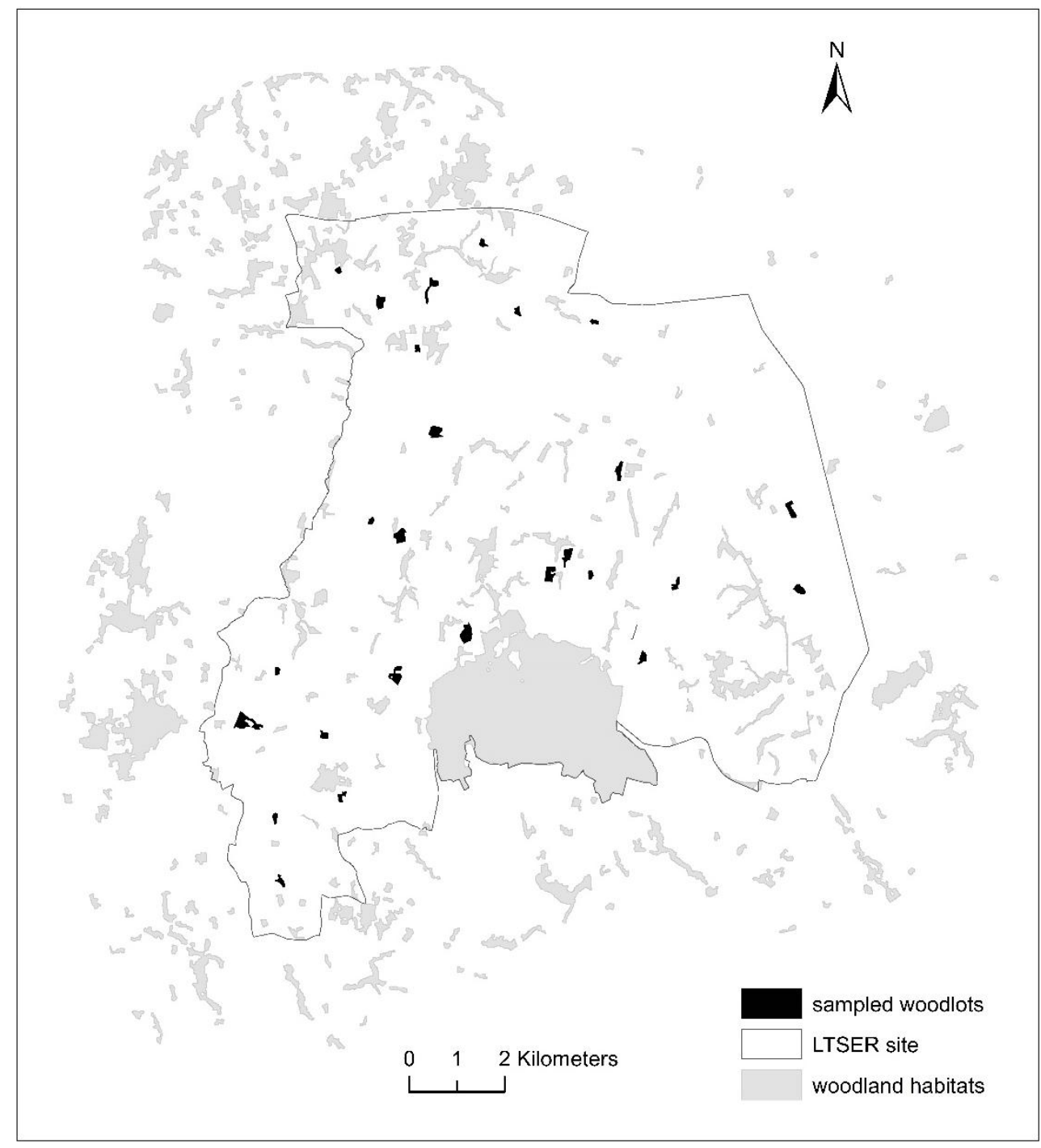


Figure 2: Effect of woodlot area on zoochorous relative richness for total and core assemblages.
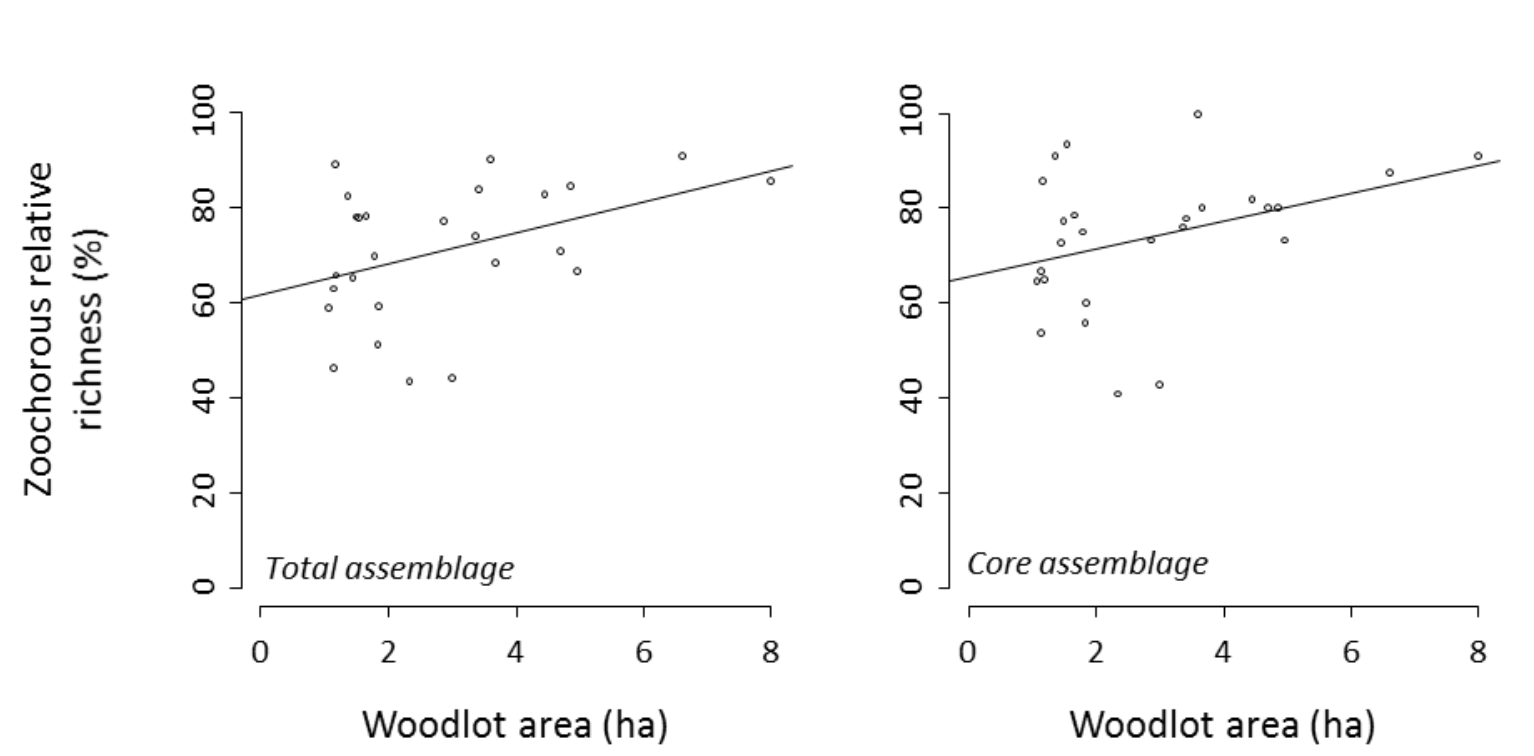
Figure 3: Interactive effect of connectivity and woodlot area on endo- and epizoochorous species and of woodlot area on dyszoochorous species for total assemblages. Three levels of woodlot size were chosen to plot the interaction effects on traits values: the lowest value of woodlot size, the average (mean) value of woodlot size, and the highest value of woodlot size.

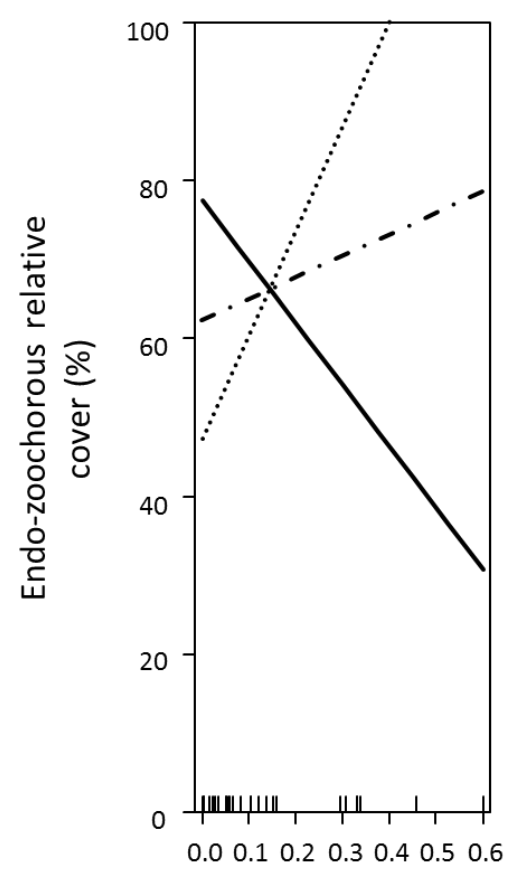

Connectivity (dF*)

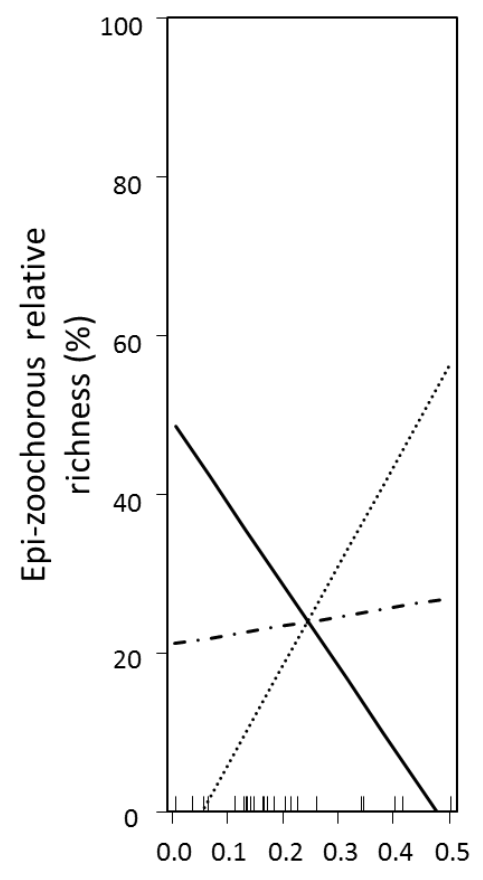

Connectivity $\left(\mathrm{dF}^{*}\right)$

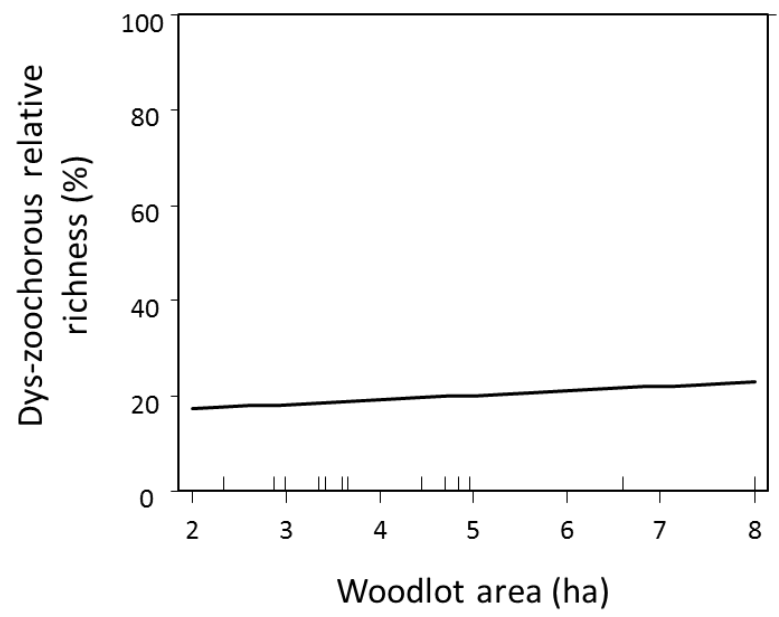




\section{APPENDIX A}

Figure A.1: Representation of the woodlands in the study area (woodland habitats in gray and sampled woodlots in black) and the links or potential connections corresponding to the sampled woodlots and according to a planar graph (i.e., only neighboring patches can be linked).

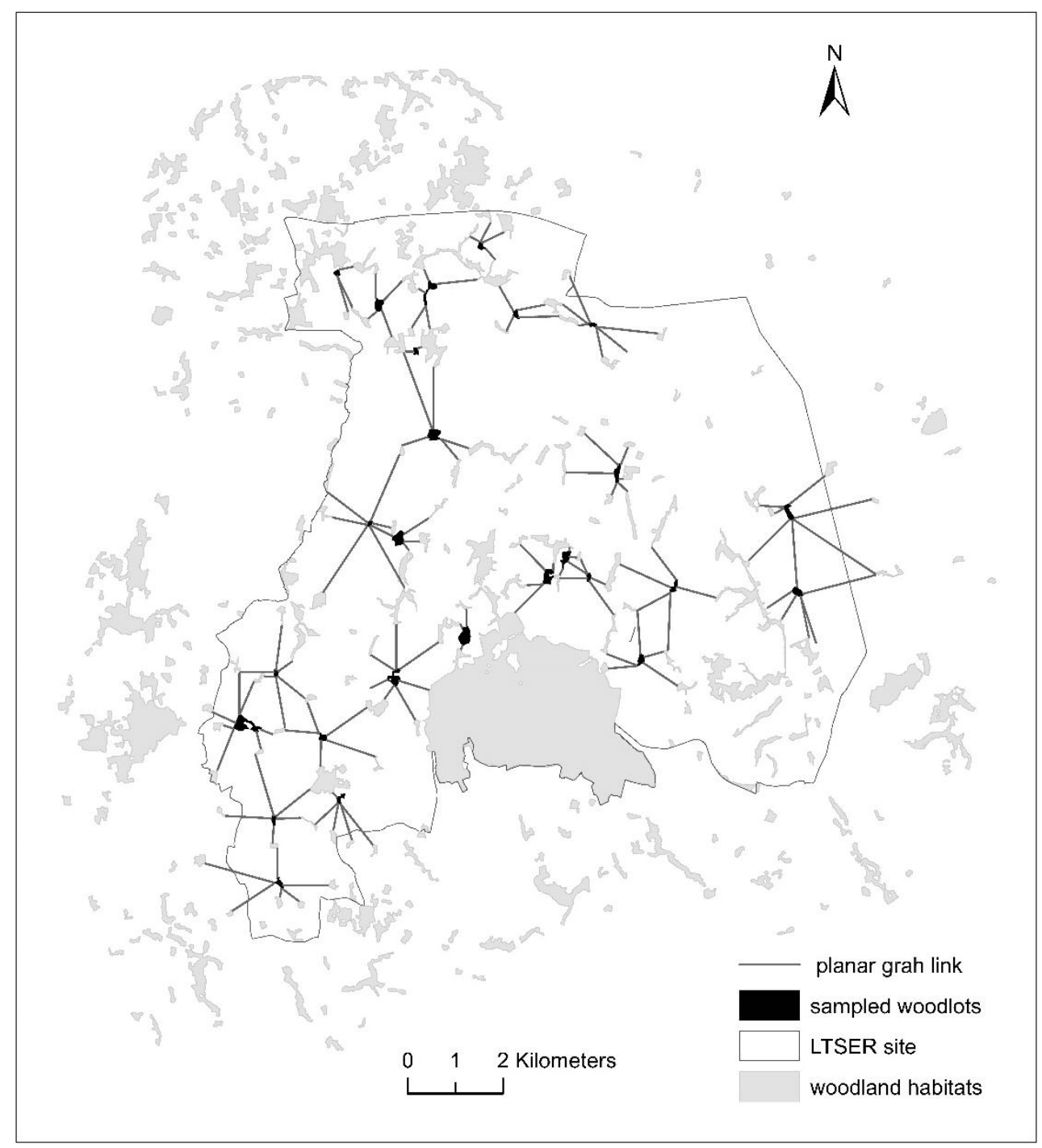


Table A.1. Sampled woodlot area and shape and descriptive statistics of interpatch Euclidean distances of the sampled woodlots relative to the other woodlots in the study area. Euclidean distances were calculated based on the planar graph used to compute connectivity analysis (See Figure B.1).

\begin{tabular}{|c|c|c|c|c|c|c|}
\hline \multirow{3}{*}{$\begin{array}{l}\text { Sampled } \\
\text { woodlot } \\
\text { identificator }\end{array}$} & \multicolumn{2}{|c|}{$\begin{array}{l}\text { Sampled woodlot } \\
\text { characteristics }\end{array}$} & \multicolumn{4}{|c|}{ Sampled woodlot context } \\
\hline & \multirow{2}{*}{ Area (ha) } & \multirow{2}{*}{ Shape } & \multirow{2}{*}{$\begin{array}{l}\# \text { of } \\
\text { neighboring } \\
\text { woodlots }\end{array}$} & \multicolumn{3}{|c|}{ Distance (m) } \\
\hline & & & & $\min$ & $\max$ & mean \\
\hline 1 & 1.78 & 0.04 & 6 & 151.33 & 1494.52 & 773.33 \\
\hline 2 & 1.54 & 0.04 & 5 & 340.59 & 1325.63 & 800.06 \\
\hline 3 & 1.66 & 0.04 & 5 & 113.14 & 1082.31 & 627.88 \\
\hline 4 & 8.00 & 0.03 & 7 & 199.25 & 893.20 & 544.13 \\
\hline 5 & 1.17 & 0.04 & 6 & 190.00 & 1067.05 & 659.56 \\
\hline 6 & 4.44 & 0.03 & 7 & 330.15 & 962.60 & 657.95 \\
\hline 7 & 6.60 & 0.02 & 3 & 67.08 & 320.16 & 157.56 \\
\hline 8 & 4.97 & 0.02 & 4 & 164.01 & 593.63 & 389.89 \\
\hline 9 & 4.84 & 0.02 & 5 & 546.72 & 1686.56 & 932.24 \\
\hline 10 & 1.13 & 0.04 & 2 & 72.80 & 160.00 & 116.40 \\
\hline 11 & 3.67 & 0.02 & 4 & 220.23 & 575.85 & 458.42 \\
\hline 12 & 1.17 & 0.04 & 4 & 10.00 & 762.43 & 442.48 \\
\hline 13 & 3.35 & 0.04 & 5 & 138.92 & 844.81 & 441.97 \\
\hline 14 & 1.49 & 0.04 & 4 & 214.71 & 487.54 & 352.06 \\
\hline 15 & 1.44 & 0.04 & 4 & 331.06 & 820.24 & 577.17 \\
\hline 16 & 2.99 & 0.03 & 6 & 70.00 & 980.20 & 476.23 \\
\hline 17 & 3.60 & 0.03 & 4 & 60.00 & 463.25 & 194.12 \\
\hline 18 & 4.69 & 0.03 & 4 & 130.00 & 834.39 & 504.09 \\
\hline 19 & 1.37 & 0.04 & 5 & 308.71 & 852.12 & 496.56 \\
\hline 20 & 1.85 & 0.04 & 5 & 782.94 & 1201.04 & 958.52 \\
\hline 21 & 2.34 & 0.03 & 5 & 405.22 & 892.02 & 672.90 \\
\hline 22 & 2.86 & 0.02 & 6 & 560.80 & 1559.55 & 998.83 \\
\hline 23 & 3.43 & 0.03 & 7 & 205.91 & 2041.30 & 1126.95 \\
\hline 24 & 1.06 & 0.04 & 6 & 191.05 & 1287.63 & 773.45 \\
\hline 25 & 1.14 & 0.04 & 7 & 390.51 & 1644.69 & 1096.74 \\
\hline
\end{tabular}




\section{APPENDIX B}

Table B1. Decreasing friction values used to model landscape matrix permeability based on the vertical structure of the land uses (see also Watts et al. 2010) according to an exponential function with a maximum friction threshold of 50 .

\begin{tabular}{ll}
\hline Land-use & Friction value \\
\hline Woodlands and forests $\geq 1$ ha & 1 \\
Hedgerows and woodlands $<1$ ha & 2.57 \\
Semi-natural and managed grasslands & 6.84 \\
Crops & 18.40 \\
Water bodies and watercourses & 18.40 \\
Artificial lands (urban areas and roads) & 50
\end{tabular}

